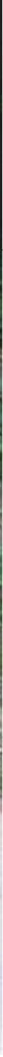

Schmidt László

\title{
Az amerikai haderő GMC CCKW terepjáró tehergépkocsija
}

1

939-ben az Egyesült Államok hadseregében, a járműállomány áttekintése nyomán, a Quartermaster Corps (a QM Corps a három US ARMY logisztikai egység egyike; a másik kettő a Transportation Corps és az Ordnance Corps) tendert hirdetett meg 2,5 tonnás, 6×6 kerékképletű járművek szállítására. A felkínált járművek között volt a Yellow Truck \& Coach Manufacturing Co (GMC) ACKWX-353 típusjelű teherautója is. Ez a gépkocsi a gyár AC megjelölésű, polgári célokra készült, a tenderen való részvétel miatt némileg módosított járműve volt, egy 4,2 I-es benzinmotorral, és 4+1 fokozatú mechanikus sebességváltóval.

A gépkocsi megfelelt a kiírásban megjelölt elvárásoknak, és a rövidesen létrejött megrendelés alapján, már 1940ben közel 2500 darabot le is szállítottak az amerikai hadseregnek. Az üzemeltetés első tapasztalatainak kiértékelése

ÖSSZEFOGLALÁS: A 2,5 tonnás, $6 \times 6$ kerékképletű GMC katonai teherautó 91,5 LE-s, hathengeres benzinmotorja 4,4 literes, sebességváltója pedig 5+1 fokozatú volt. A GMC CCKW széria gyártása 1945-ben, összesen 562750 példány legyártása után állt le. A típust az amerikai hadvezetés a második világháború valamennyi hadszínterén alkalmazta. GMC tehergépkocsikat nagyobb számban még a szövetséges Szovjetunió, kisebb mennyiségben Franciaország kapott. A háború után megalakult Magyar Honvédség jármúparkjában ez a típus 1948-tól közel kétezres példányban volt jelen.

KULCSSZAVAK: Egyesült Államok hadereje, II. világháború, GMC CCKW katonai teherautó nyomán, már ugyanazon év őszén, ennek a típusnak egy módosított, „militarizáltabb” változatát gyártották CCKWX353 típusjelzéssel. Ebben az első „C” az 1941-es évet, a második „C" a standard kivitelt, a „K” az első-, a „W” a hátsókerék-meghajtást, az „X” valami különlegességet, pl. külső beszállítótól vásárolt részelemet jelentett. Ennek a változatnak motorja már nagyobb, 4,4 literes (91,5 LE-s), sebességváltója pedig $5+1$ fokozatú volt.

A GMC gyár és az amerikai ipar teljesítőképességét mutatja, hogy 1941 februárjáig már 13200 ilyen tehergépkocsit adott át a hadsereg részére. A következő, 1941. februártól júniusig terjedő időszakra érvényes szerződés szerint a gyár további 28000 gépkocsit készített.

Ugyanebben az évben a jármű típusjelöléséből eltűnt az „X”, ami külső beszállítású, idegen futóművekre utalt. Ek-

ABSTRACT: The 2.5-ton $6 \times 6$ GMC military truck had a $91.5 \mathrm{HP}$ six-cylinder petrol engine with 4.4 litres cylinder capacity, and a $5+1$ speed transmission. Production of the GMC CCKW series was ceased in 1945 after manufacturing 562,750 pieces. This type of the vehicle was used by the American military leadership in all theatres of operations of the World War II. GMC trucks were given to the allied Soviet Union in larger quantities and to France in smaller quantities. From 1948, there were approx. 2000 trucks of this type in the vehicle fleet of the Hungarian Defence Force founded after the war.

KEY WORDS: military power of the United States, World War I, GMC CCKW military truck 


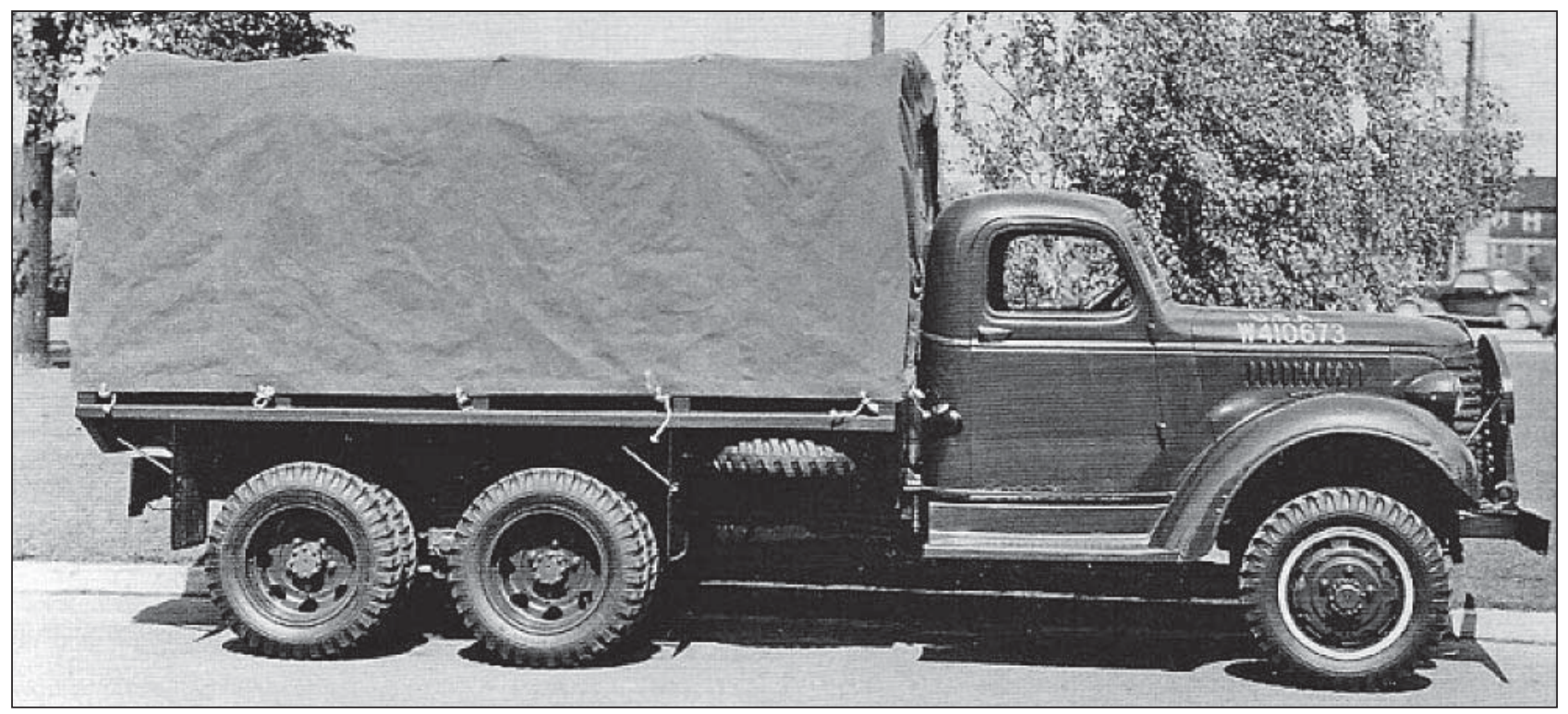

1. ábra. A tendernyertes GMC ACKWX-353-as gépkocsi, még szembetűnően polgári külsővel

kortól kerültek beépítésre a GMC gyár saját fejlesztésű, „Banjo" futóművei is. A korábbi, középen osztott hidas futóműveket azonban a „Banjo” futóművel együtt a gyártás teljes időszaka alatt (1941-1945), egymással párhuzamosan szerelték a gyártott gépkocsikba. A kétféle futómű azonban még az igen jó alkatrészellátással rendelkező amerikai hadseregnél is problémákat jelenthetett, ugyanis az eltérő futóművek miatt az alváz és a teljes hajtáslánc is két változatban került kialakításra. Különböztek a kardánok, osztóművek és a futóművek felfüggesztései is.
A CCKWX és az első CCKW tehergépkocsikat (összesen 42000 járművet) az 1. széria CCKW járműveiként jelölték meg.

A 2. széria CCKW-t (46 425 jármű) 1941 júniusától 1942 májusáig gyártották. Ezek a gépkocsik egy módosított, de még zárt vezetőfülkét kaptak, amelyek egy részét felső kibúvónyílással látták el. A fülke fölé egy külön állványon körbeforgatható, 12,7 mm-es nehézgéppuska volt szerelhető. Ezeknél a járműveknél építették be először az addig a polgári változatával szinte teljesen megegyező műszerfal helyett az egyszerűsített, katonai „szabvány” műszerfalat.

2. ábra. Már a haderő igényeinek megfelelően módosított, hosszú tengelytávú CCKWX-353-as gépkocsi alaptípusa

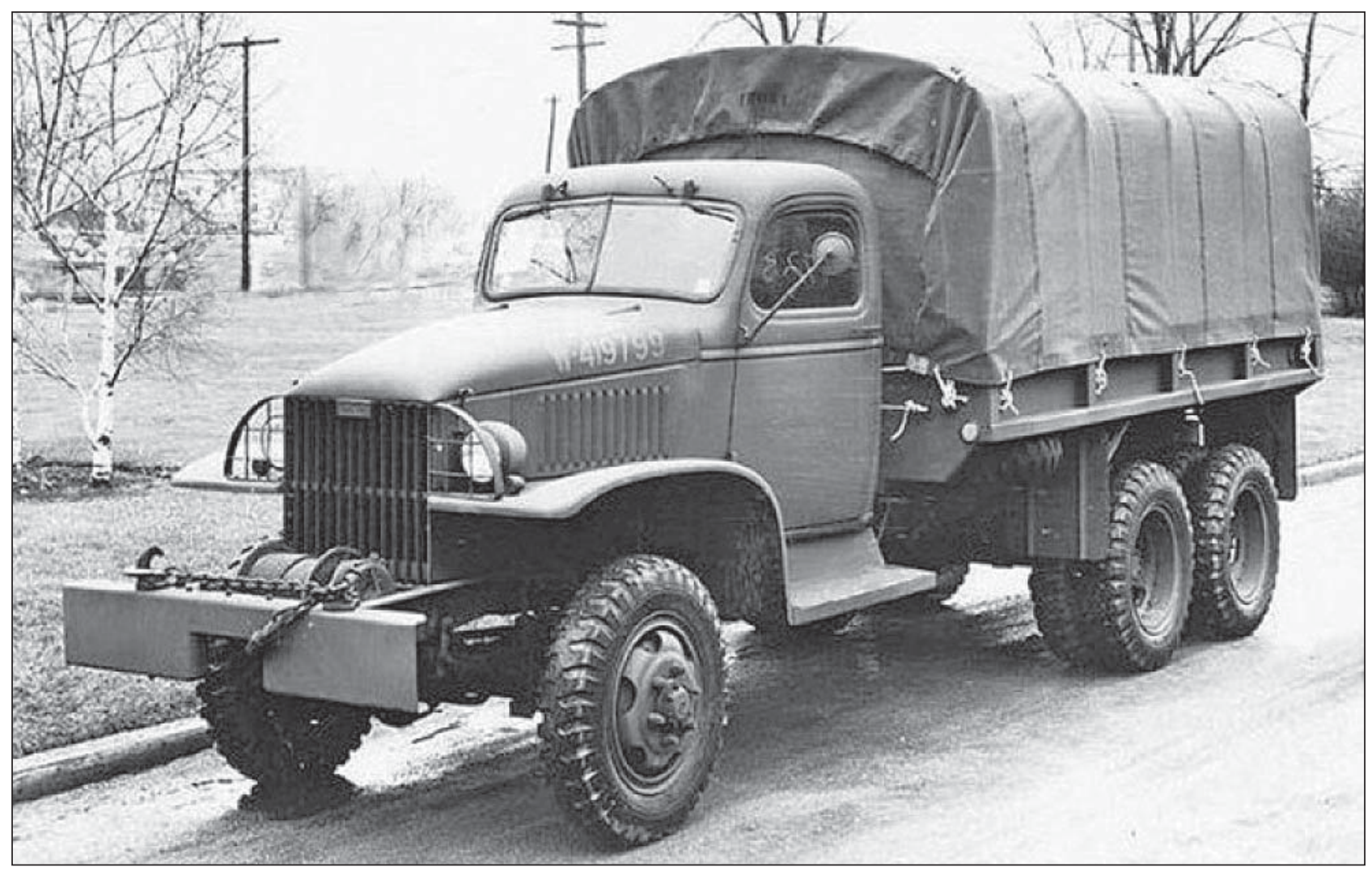




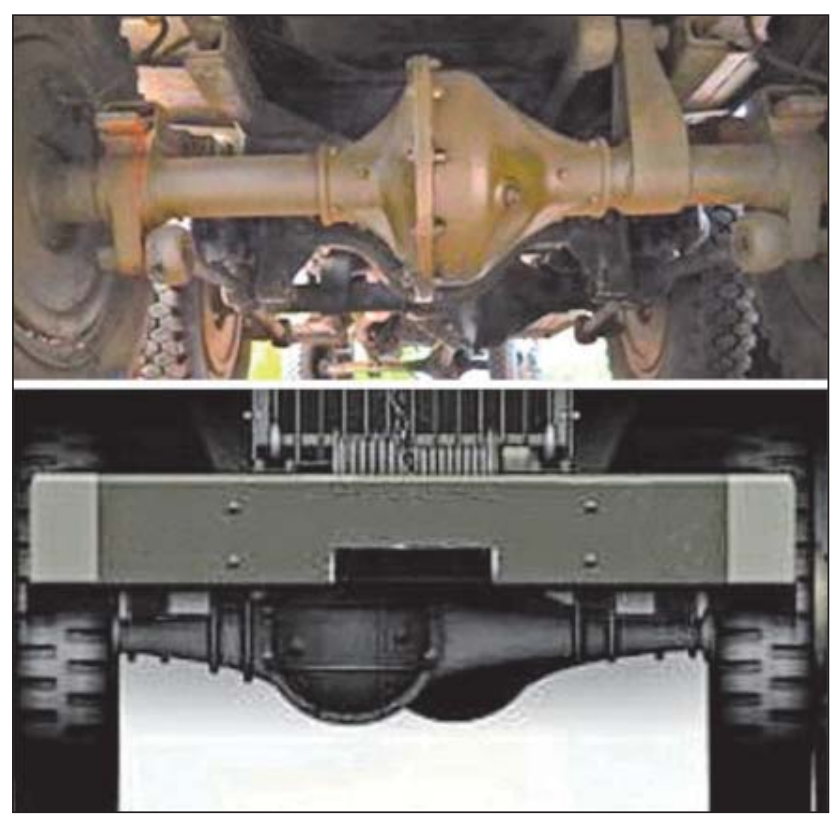

3. ábra. A két, egymástól lényegesen eltérő kialakítású futómú. Felül a külső beszállító osztott, alul a GMC gyár saját, hagyományos kialakítású hídja látható („Banjo”-híd)

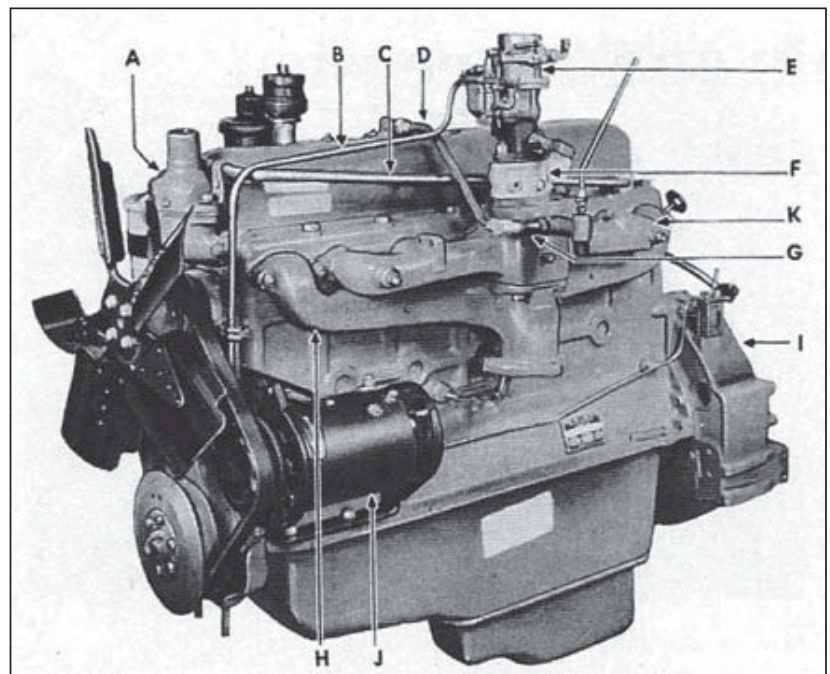

4. ábra. A 91,5 LE-s hathengeres benzinmotor bal oldali képe (A - termosztátház, B - üzemanyag-cső, C - termosztátmegkerülő cső, D - forgattyúsház-szellőzés csöve, E - karburátor, F - fordulatszám-korlátozó, G - forgattyúsház szellőző szelep, H - kipufogócsonk, I - kuplungház, J - dinamó, K - szívócsö)

A CCKW tehergépkocsik 3. szériája 1942. májustól 1943 áprilisáig készült (kb. 123600 db). A típus gyártása során, ezeken a járműveken vezették be a legtöbb módosítást. Az eddig alkalmazott háromküllős, bakelit kormánykerék helyett négyküllős, fa kormánykerekek kerültek beszerelésre. A járművekre gyárilag légoltalmi fényszórót is szereltek, és az addigi, szimmetrikus helyett, aszimmetrikus hűtőrácsot építettek a gépkocsira. Ebben az időszakban (1942 augusztusában) a hűtőre korábban szerelt GMC jelzést elhagyták, minden jármű kézifegyvertartókat kapott. A leglényegesebb változás azonban a zárt vezetőfülkék fokozatos leváltása volt egy nyitott változatra, és az, hogy a korábbi fém rakfelület 1942 augusztusától fából készült. Ez a lényeges átállás csaknem egy évig elhúzódott.
A 4. széria már kizárólag nyitott, ponyvás vezetőfülkével és fa rakodótérrel készült, 1943 áprilisától 1944 januárjáig, összesen közel 107500 példányban. Már a 4. széria kezdetén megnövelték az üzemanyag-betöltő nyílás méretét, és változtattak a vezetőfülke addig alkalmazott ponyvaborításán is.

Az 5. széria gyártása 1944 februárjában kezdődött és 1944 novemberében zárult le, 73500 elkészült gépkocsi legyártása után. Ennek a sorozatnak markáns jellemzője, hogy az alvázat - a gyakori törések miatt - az addig alkalmazott 6,4 mm-es helyett már $8 \mathrm{~mm}$-es acéllemezből gyártották és szerkezetét további elemekkel erősítették meg.

A 6. széria 1944 novemberétől 1945 augusztusáig gyártott, több mint 168000 járművénél módosítást alig végeztek, említésre méltó talán, hogy a csörlővel készült tehergépkocsik acélsodronyát fele hosszúságúra (45 m) csökkentették.

Az Egyesült Államok európai szemmel nézve döbbenetes ipari potenciálját szemlélteti, hogy a GMC CCKW széria gyártása 1945 augusztusában, összesen 562750 példány legyártása után állt le. Az elkészült teljes mennyiségből a CCKW 353 típus (LWB=hosszú tengelytávú) mintegy 70\%ot tett ki, a 352-es típus (SWB= rövid tengelytávú) csak mintegy $10 \%$-os arányt képezett.

A gyártott gépkocsik az alaptípuson túl számtalan más felépítménnyel is készültek, mindkét tengelytávval. Így volt billenőplatós, üzemanyag- és vízszállító, műhelykocsi, tűzoltó, kompresszoros és számtalan más változat is.

Ezt a típust az amerikai hadvezetés a második világháború valamennyi hadszínterén alkalmazta. Az azonos kategóriájú más amerikai tehergépkocsik, mint a Studebaker US6, vagy a Chevrolet YS4103 lényegesen kisebb darabszámban készültek, így kevésbé voltak elterjedtek. A Studebaker pl. jelentős mértékben a Lend-Lease szállítások anyagát képezte. GMC tehergépkocsikat nagyobb számban még a szövetséges Szovjetunió, kisebb mennyiségben Franciaország kapott.

A háború után a megmaradt állomány egy része 1949-től a NATO tagországok gépkocsiállományába került. Sok

\section{5. ábra. A gépkocsi szabvány müszerfala a kezelőszervekkel}

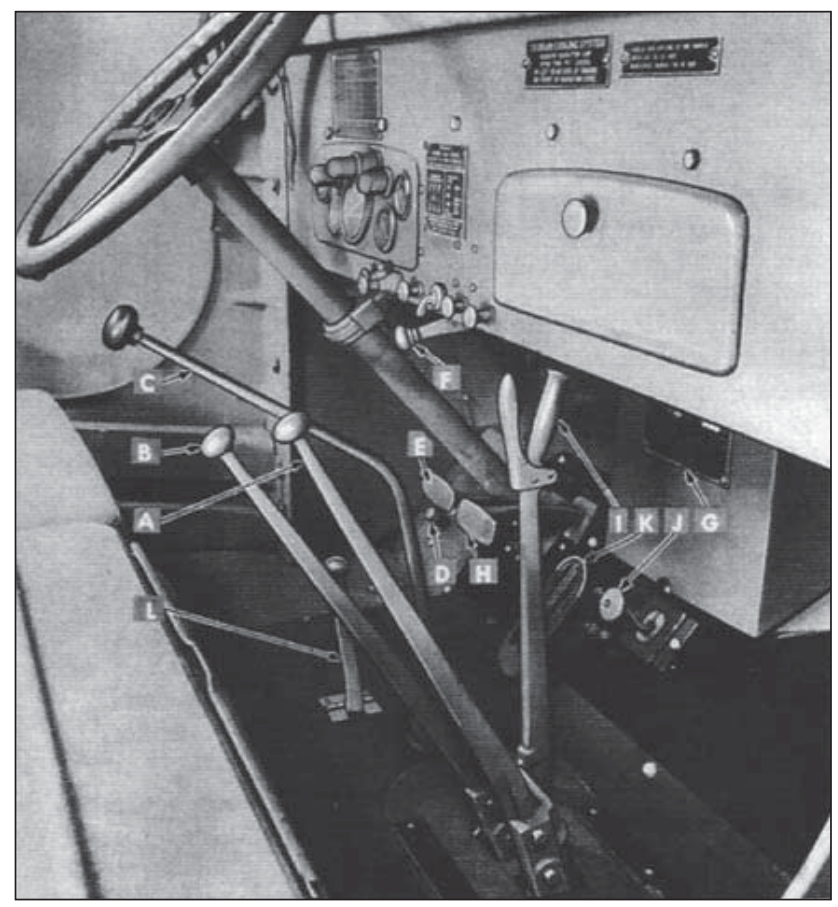




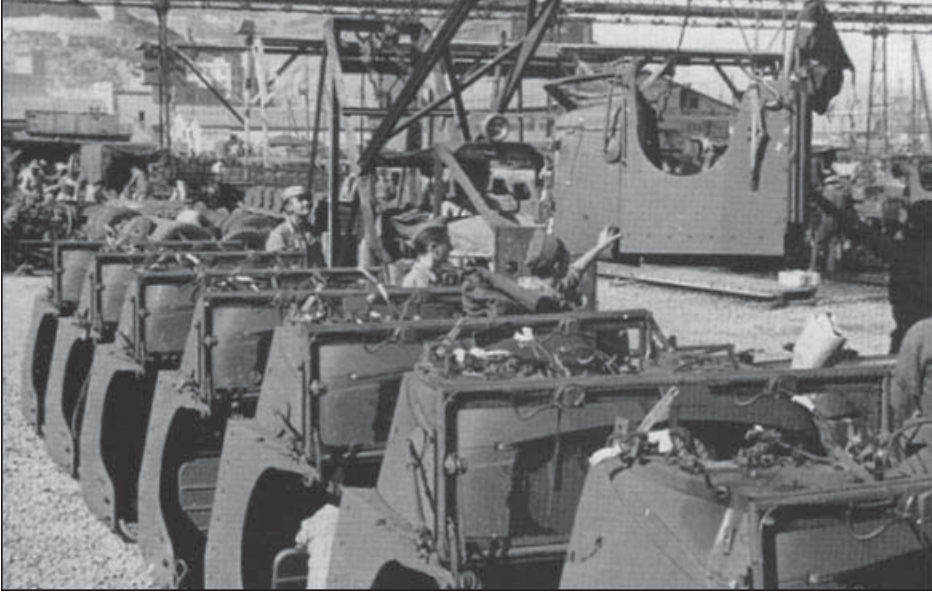

6. ábra. A képen az USA-ból pótlásként érkező nyitott vezetőfülkék kirakodása látható. A szállítmányra nemcsak a fokozott igénybevétel, hanem az erős korrózió miatt is szükség volt

példánya még a koreai és a vietnami háborúban is részt vett, majd az '50-es évek közepétől a GMC egy korszerübb változatú tehergépkocsija váltotta le ezt a típust.

A 2,5 tonnás GMC CCKW-352/353 szokványos szerkezetű és felépítésű összkerékhajtásos tehergépkocsi volt. Erőforrása egy GMC 270-es, hathengeres benzinmotor. Ennek fogyasztásáról egyértelmű adatot nehéz találni, de tény, hogy a gépkocsi háború utáni civil működéséhez német autójavító cégek „takarékos Henschel dízelmotor” beépítését kínálták és végezték. Tekintetbe véve az új motor, valamint az átépítés költségeit, az eredeti motor a polgári életben nem lehetett gazdaságos üzemű.

Az elsőkerékhajtás egy kétfokozatú osztóművel volt kapcsolható, amelynek segítségével a „lassú” és „gyors” állást is választani lehetett, ami gyakorlatilag a sebességfokozatok számát megduplázta.

7. ábra. Az 1948-ban, a budapesti Nyugati pályaudvarnál készült képen honvédeket szálítanak egy hosszú tengelytávú GMC tehergépkocsin. A háttérben a Lehel téri templom látható

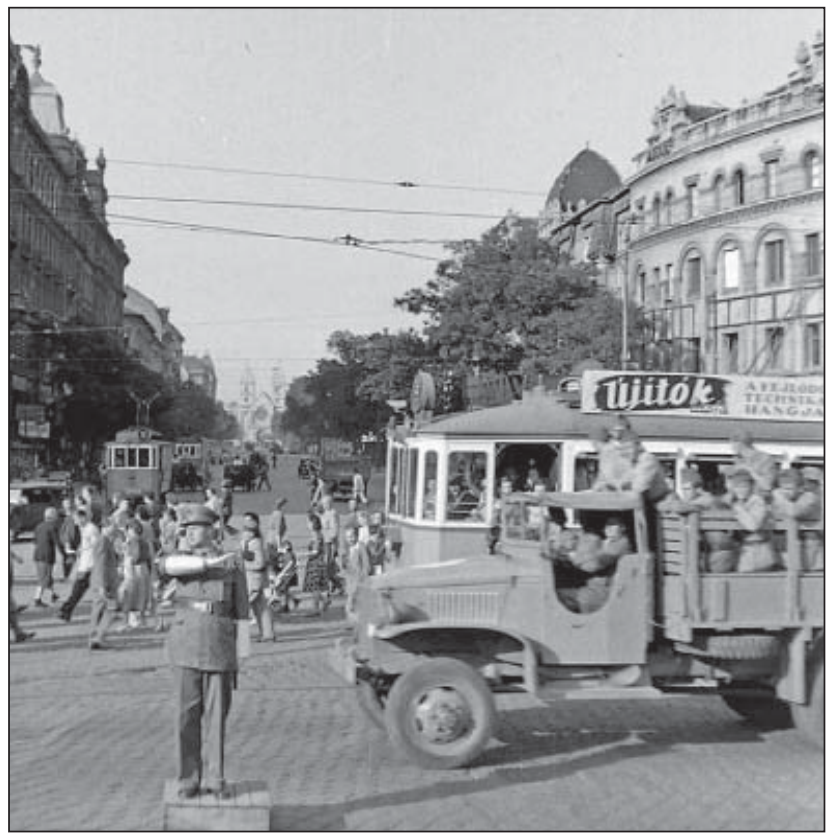

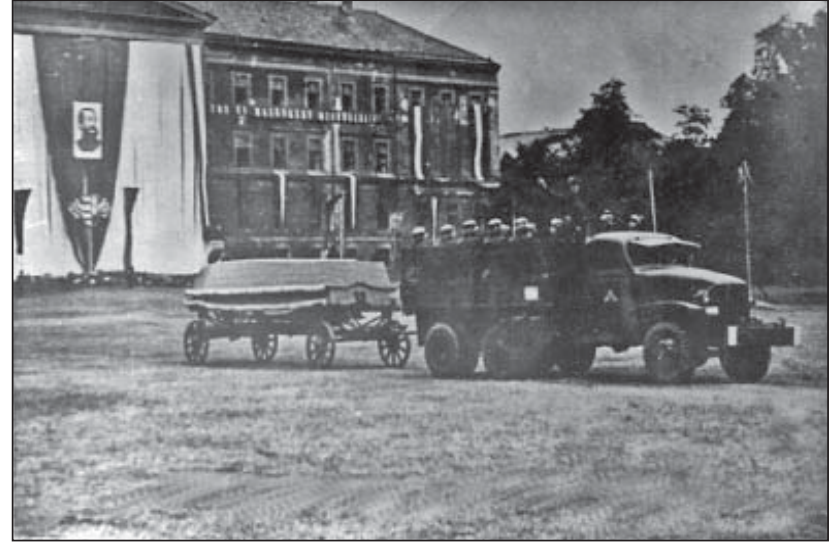

8. ábra. Az 1948-ban, a Kossuth Akadémia (Ludovika) előtt készült fotó egy zárt vezetöfülkés GMC tehergépkocsit mutat, egy hozzákapcsolt, vele nem egészen egy müszaki szintet képviselő pontonszállító utánfutóval

A sebességváltóra a gépkocsi fajtájától és felszereltségétől függően segédkihajtás volt szerelhető, amely a csörlőt, vagy a billenő-hidraulika szivattyúját hajtotta meg.

Üzemi fékberendezése levegő-rásegítéses olajfék, a kézifék (szalag) az osztóműre szerelt hengerre hatott.

Az első futóművet és a sárvédőt úgy alakították ki, hogy szükség esetén az első kerekek is „duplázhatóak” voltak. Ennek azonban gyakorlati haszna alig volt, mert a túl nagy felfekvő felületek csökkentették ugyan a talajnyomást, de így a kerekek tapadását is.

A két típus közül a 353-as egy, a plató alatt fekvő helyzetü, a 352-es változat két, a vezetőfülke mögött álló pótkerékkel volt felszerelve.

Az üzemanyagtartályok is eltérőek voltak. A hosszú tengelytávú változatnál a plató alatt jobb oldalt elöl téglatest formájú, a rövid tengelytávúnál keskeny, de széles, hasáb formában a két álló pótkerék alatt kapott helyet. Ez utóbbinak, praktikus módon mindkét oldalon volt töltőnyílása.

Érdekes még, hogy a katonai gépjárművek között is ritkán előforduló kiegészítéssel a jármű gázlómélységét 76ról $90 \mathrm{~cm}$-re lehetett növelni. A levegőszűrő helyére, illetve a kipufogócsonkra szerelt két flexibilis fémcsövet a motortér oldalsó borítólemezei mellett kivezetve, a szélvédő két oldalán kellett rögzíteni.

Ugyancsak ritka megoldást kínált a gyár e tehergépkocsinak korlátozott belső terű repülőgépen szállításához. Készült ennek a GMC-nek egy olyan (airportable version) változata, ahol az alváz keresztben, a vezetőfülke mögött két részre volt osztva, azokat csavarkötések kapcsolták össze. A két alvázdarab a végeire szerelt mankókerekek segítségével könnyebben volt rakodható, mozgatható.

A háború után megalakult Magyar Honvédség (majd 1951. június 1-jétől a Magyar Néphadsereg) járműparkjában ez a típus 1948-tól előbb néhány tucat, majd ismételt megrendelések (1949. április: 246, 1950. május: $1443 \mathrm{db}$ ) nyomán jelentős, közel kétezres példányban volt jelen. A rendelkezésre álló adatok szerint 1950 augusztusában már 1700 GMC volt a Honvédség állományában. Ezek közül 1949-ben 100 példány érkezett felépítmény nélkül, csak vezetőfülkével. Kisebb darabszámban a rendőrség is kapott ilyen teherautókat. A vásárolt gépkocsik kevés kivétellel nyitott vezetőfülkével érkeztek, java részük platós kivitelben, de a Honvédség vásárolt speciális felépítményű változatokat is.

A beszerzés jelentősebb forrása Bizónia (a második világháború után a németországi angol-amerikai egyesített megszállási övezet neve) volt, ahonnan a győztes hatalmak 
1. táblázat. A GMC típusok föbb müszaki adatai:

\begin{tabular}{|c|c|c|}
\hline GMC CCKW (csörlő nélkül) & 353 & 352 \\
\hline Gépkocsi súlya & $5100 \mathrm{~kg}$ & $5000 \mathrm{~kg}$ \\
\hline Hasznos terhelhetőség & $2270 \mathrm{~kg}$ & $2270 \mathrm{~kg}$ \\
\hline Teljes méret $(\mathrm{h} \times \mathrm{sz} \times \mathrm{m})(\mathrm{mm})$ & $6500 \times 2250 \times 2850$ & $5810 \times 2250 \times 2850$ \\
\hline Tengelytávolság & $4170 \mathrm{~mm}$ & $3680 \mathrm{~mm}$ \\
\hline Hasmagasság & $250 \mathrm{~mm}$ & $250 \mathrm{~mm}$ \\
\hline Motor & $\begin{array}{c}\text { 4,4 literes, } 6 \text { hengeres, vízhűtéses, } \\
\text { soros benzinmotor, 91,5 LE }\end{array}$ & $\begin{array}{c}\text { 4,4 literes, } 6 \text { hengeres, vízhűtéses, } \\
\text { soros benzinmotor, 91,5 LE }\end{array}$ \\
\hline Üzemanyagtartály térfogata & 151 liter & 151 liter \\
\hline Üzemanyag-fogyasztás & - & - \\
\hline Sebességek száma & $5+1(\times 2)$ & $5+1(\times 2)$ \\
\hline Legnagyobb sebesség & 72 km/ó & 72 km/ó \\
\hline Lejtőmászó képesség & $65 \%$ & $65 \%$ \\
\hline Gázlóképesség & $76 \mathrm{~cm}$ & $76 \mathrm{~cm}$ \\
\hline Gumiabroncs mérete & $7,50-20$ & $7,50-20$ \\
\hline Fordulási kör & $1067 \mathrm{~cm}$ & $1036 \mathrm{~cm}$ \\
\hline
\end{tabular}

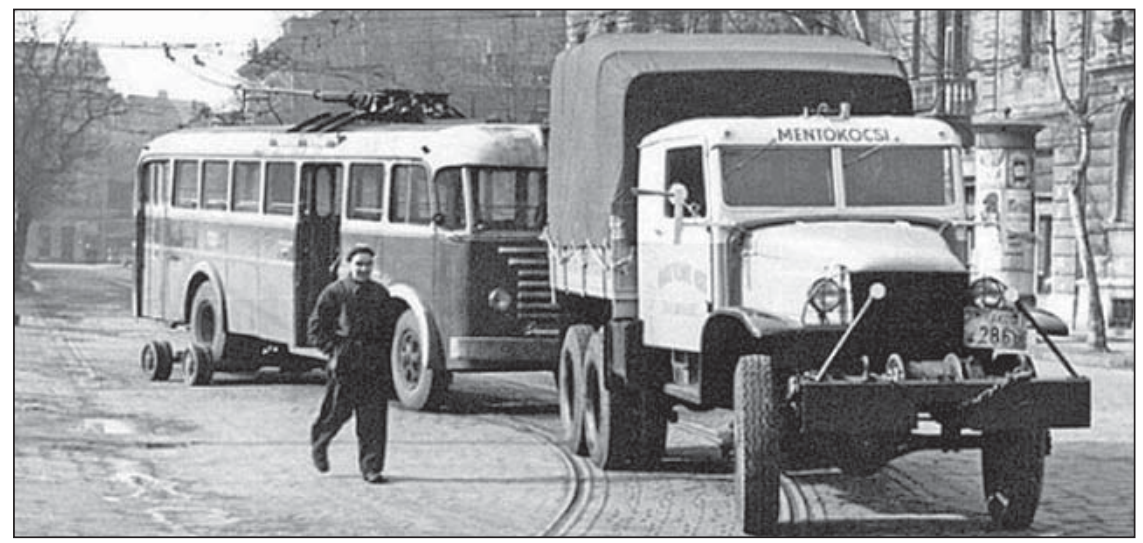

9. ábra. A fotó az 1960-as években készült, Budapesten. A hibás Ikarus 60T trolibuszt egy műszaki mentővé alakított GMC vontatja. Az eredeti, nyitott vezetőfülkét a Csepel 350-es tehergépkocsi másfél (!) fülkéjére cserélték. A trolibusz hátsó kerekei alatt egy német Pz. IV harckocsi futógörgőibőll készült mankókocsi látható

10. ábra. Talán az utolsó GMC CCKW-353-as Magyarországon. A mintegy 10 évvel ezelött készült fotó egy filmtársaság kellék-gépkocsiparkjának egy részletét mutatja

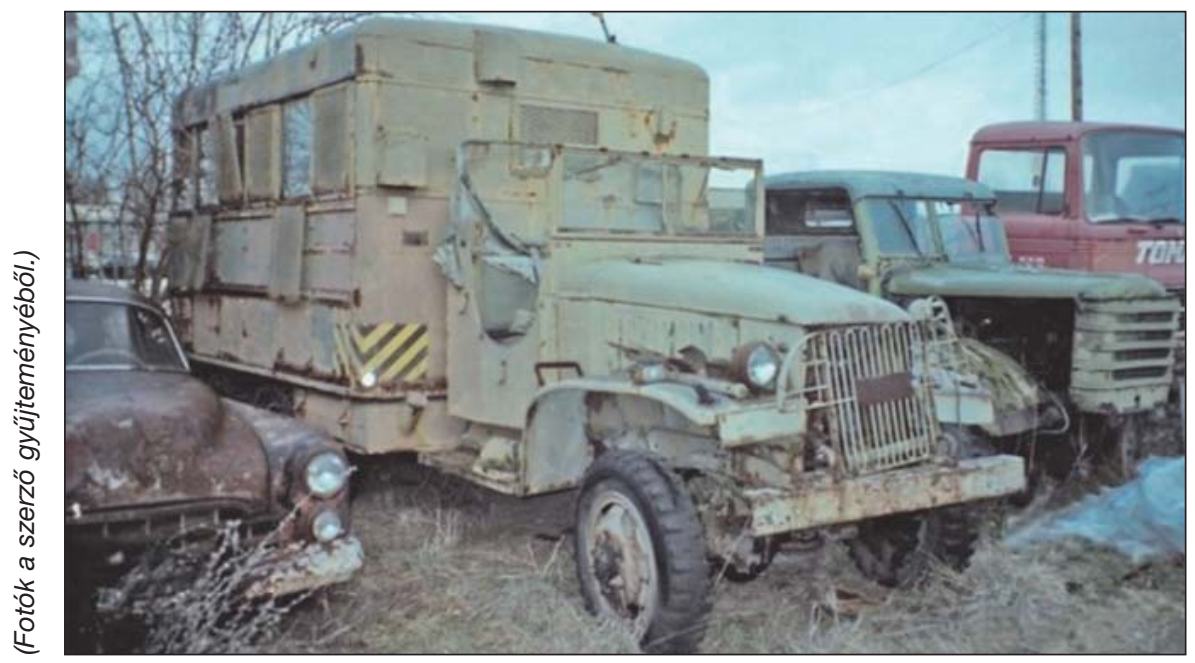

Európába áthozott, és a háború után feleslegessé vált gépkocsiállományuk egy részét (is) kiárusították.

Kerülhetett azonban a Honvédséghez esetleg az 1948 februárjában megkötött szovjet-magyar fegyverszállítási egyezménnyel is ilyen jármű, mert néhány, az 1950-es években sorkatonai szolgálatot teljesítő személy visszaemlékezése szerint cirill betűs felirattal is üzemeltek GMC tehergépkocsik a magyar fegyveres erőknél.

A két korábbi nagy szövetséges egymástól való elhidegülésével, és 1951-től, a hasonló felépítésű Csepel D-300-as magyar tehergépkocsi gyártásával, az alkatrészek beszerzése megszűnt. Így az addigra müszakilag avult gépkocsik fokozatosan selejtezésre kerültek, és a második „ötéves terv" során, 1961-65 között az utolsó darabok is eltűntek a Honvédség állományából. Az eredetileg jó minőségű járművek egy része azonban még további alkalmazást talált a polgári életben is, különböző vállalatok gépkocsiállományában.

\section{FoRRÁSOK}

Bart H. Vanderveen: Fighting Vehicles Directory World War II. Frederick Warne \& Co, London, 1969;

Fred W. Crismon: U.S. Military

Wheeled Vehicles;

www. gmccckw.nl;

www.fortepan.hu;

Varga Imre úr szíves közlései. 